\title{
FATTY ACYLATION OF PROTEINS
}

Michael F.G. Schmidt

Faculty of Medicine-Department of Biochemistry

Kuwait University

P.O. Box 24923 / Code 13110 - SAFAT

Kuwait - Arabian Gulf

and

Marion Schmidt

Institut für Virologie

Justus-Liebig-Universität Giessen

Frankfurter Strasse 107

D-6300 Giessen, F.R.G.

\section{Introduction}

The various biosynthetic modifications of proteins, as for instance the addition of oligosaccharides, phosphate groups and fatty acid chains have become an important area of study in the biomedical sciences. Especially in a time where cloned eukaryotic genes are expressed in bacterial (or other alien) systems yielding non-modified protein products for medical application it would be of interest to know what the biological implications are of using such "unnatural" proteins. Accordingly, three lines of investigations are in progress which aim at the structural analysis of a given modification, elucidating its various biological functions and at an understanding of the biosynthetic event of the modification. 
Here we would like to focus on the hydrophobic modification through covalent linkage of fatty acyl chains, mainly palmitic acid, to a polypeptide backbone. In nature this seems to be verified by three biosynthetic mechanisms, palmitoylation, myristilation and through covalent linkage of phosphotidylinositol to an extended carboxyterminus (for reviews see Schmidt, 1983; Sefton and Buss, 1987; Low et al., 1986).

Following the first reports of fatty acids in polypeptides (Folch-Pi, and Lees, 1951; MacLennan et al., 1972) it was generally believed that this modification would be restricted to a highly specialized class of proteins soluble in organic solvents. When fatty acylation was observed also in typical membrane glycoproteins (Schmidt et al., 1979; Schmidt and Schlesinger, 1979) a subsequent quest for such acylation revealed its wide distribution in nature across all levels of development. Myristic acid in a protein was first detected with cAMP-dependent protein kinase (Carr et al., 1982) and later shown to occur also with various tumor virus related proteins (Schultz et al., 1985). It was then also established that the palmitoylation mentioned above differs principally from this latter myristilation since different sets of proteins were acylated with palmitic acid (Pal) or myristic acid (Myr) in a given cell species. Likewise, the linkage properties differed in these two types of acylproteins (Magee and Courtneidge, 1985; McIlhinney et al., 1985; see below). In order to give an idea of the wide distribution of hydrophobic modifications of proteins in nature, such proteins are listed in tables $1-5$. Especially with the cellular acylproteins the great functional variety of the respective protein species is striking, whereas with the virus specific acylproteins some common features have become apparent (see below). 
TABLE 1

\section{CELLULAR PROTEINS ACYLATED WITH PALMITATE}

\section{ACYLPROTEIN SPECIES}

\section{VINCULIN}

MHC, HLA B7 HEAVY CHAIN

MHC, HLA DR HEAVY CHAIN

Ia INVARIANT CHAIN

GOLGI MANNOSIDASE II

CONTACT SITE A GP, ACTIN (D.discoideum)

ANKYRIN

APOLIPOPROTEIN I

INTERPHOTORECEPTOR RETINOID-BINDING PROTEIN

MURINE ERYTHROCYTE SIALOGLYCOPROTEINS

IgE RECEPTOR

TRANSFERRIN RECEPTOR

GOLGI GALACTOSYLTRANSFERASE

SALIVARY MUCOUS GP's

INSULIN RECEPTOR

p21ras

PROTEOLIPOPROTEIN (MYELIN)

RHODOPSIN

LIPOPHILIN

a-FACTOR (YEAST)

TGF- $\alpha$ PRECURSOR

BUTYROPHILIN

XANTHINOXIDASE

RAS1， RAS2， (YEAST)

$\mathrm{Ca}^{2}+$-ATPáse (SARCOPLASMIC)

DM20 (BRAIN MYELIN)

PO (SCIATIC NERVE MYELIN)

ACETYLCHOLINE RECEPTOR

DEVELOPMENTAL GP'S (SEA URCHIN)

\section{REFERENCE}

Burn and Burger, 1987

Kaufman et al., 1984

Kaufman et al., 1984

Koch and Hammerling, 1985

Moreman and Touster, 1985

Stadler et al., 1984

Staufenbiel and Lazarides, 1986

Hoeg et al., 1986

Bazan et al., 1985

Dolci and Palade, 1985

Kinet et al., 1985

Omary and Trowbridge, 1981

Strous et al., 1983

Slomiany et al., 1983

Magee and Siddle, 1986

Sefton et al., 1982

Agrawal et al, 1982

$\mathrm{O}^{\prime}$ Brien and Zatz, 1984

Folch-Pi and Lees, 1951

Betz et al., 1987

Bringman et al., 1987

Keenan et al., 1982

Keenan et al., 1982

Fujiyama and Tamanoi, 1986

Mac Lennan et al., 1982

Agrawal et al., 1982

Agrawal et al., 1983

Olson et al., 1984

Bolanowski et al., 1984 
TABLE 2

\section{VIRAL PROTEINS ACYLATED WITH PALMITATE}

\section{VIRUS SPECIES}

$\begin{array}{ll}\text { SEMLIKI FOREST VIRUS } & \text { E1, E2 } \\ \text { SINDBIS VIRUS } & \text { E1, E2 } \\ \text { VESICULAR STOMATITIS VIRUS } & \mathrm{G} \\ \text { INFLUENZA VIRUSES } & \mathrm{HA} 2 \\ \text { SIMIAN VIRUS 40 } & \text { TAg } \\ \text { CORONAVIRUS (MURINE, BOVINE) } & \text { E2 } \\ \text { ADENOVIRUS 12 (Ad 12) } & \mathrm{Eb} 18 \mathrm{~K} \\ \text { HERPES SIMPLEX VIRUS } & \mathrm{gE} \\ \text { LA CROSSE VIRUS } & \mathrm{G} 1, \mathrm{G} 2 \\ \text { SPLEEN FOCUS FORMING VIRUS } & \mathrm{gp} 65 \\ \text { MOUSE MAMMARY TUMOR VIRUS } & \mathrm{gp} 78, \mathrm{gp} \mathrm{70,38} \\ \text { VACCINIA VIRUS } & \mathrm{p} 37 \\ \text { ADENOVIRUS 2 (Ad 2) } & 72 \mathrm{~K} \\ \text { NEWCASTLE DISEASE VIRUS } & \mathrm{F} \\ \text { MUMPS VIRUS } & \mathrm{F} \text { (HN) } \\ \text { PARAMYXO VIRUS YUCAIPA } & \mathrm{F} \\ \text { ROUS SARCOMA VIRUS } & \mathrm{gP35} \\ \text { FRIEND LEUKEMIA VIRUS } & \mathrm{p} 15 \mathrm{E}\end{array}$

\section{ACYLPROTEIN SPECIES REFERENCE}

Schmidt, 1982

Schmidt et al., 1979

Schmidt et al., 1979

Schmidt, 1982

Klockman and Deppert, 1983

Schmidt, 1982

Grand et al., 1985

Johnson and Spear, 1983

Madoff and Lenard, 1982

Srinivas and Compans, 1983

Firestone et al., 1982

Hiller and Weber, 1985

Deppert et al., 1985

Schmidt, 1982

Merz and Wolinsky, 1983

Schmidt, unpublished

Gebhardt etal., 1984

Srinivas and Compans, 1983

TABLE 3

\section{CELLULAR PROTEINS ACYLATED WITH MYRISTATE}

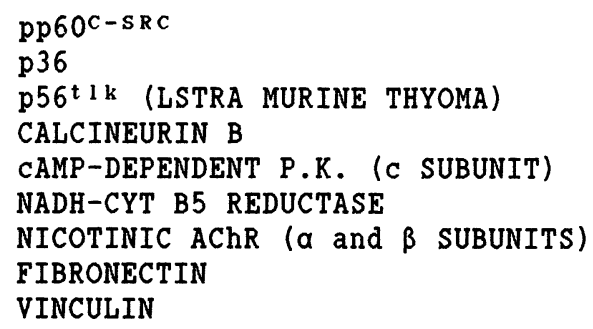

\author{
Buss and Sefton, 1985 \\ Soric and Gordon, 1985 \\ Voronova et al., 1984 \\ Aitken et al, 1982 \\ Carr et al., 1982 \\ Ozols et al., 1984 \\ Olson et al., 1984 \\ Magee, unpublished \\ Kellie and Wrigglesworth, 1987
}




\section{TABLE 4}

\section{VIRAL PROTEINS ACYLATED WITH MYRISTATE}

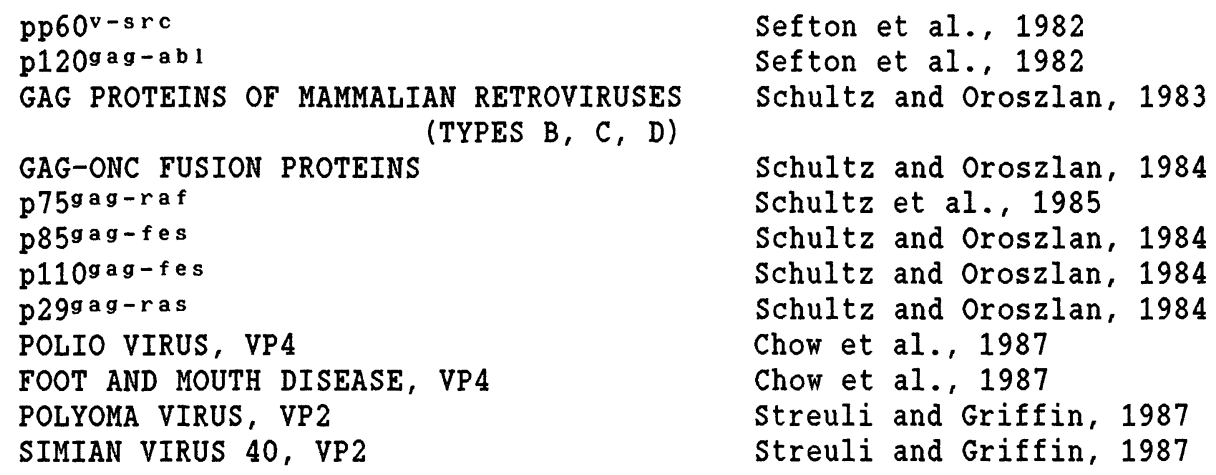

TABLE 5

\section{PROTEINS WITH ACYL CHAINS IN THEIR MEMBRANE ANCHOR (PI-TAIL)}

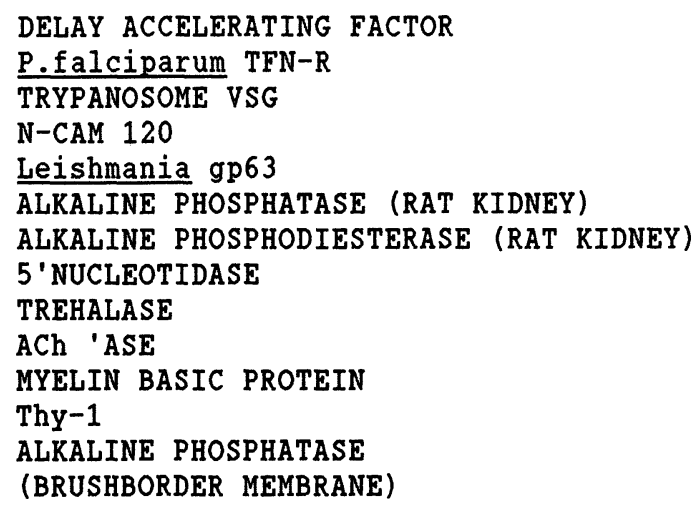

\section{Structure and Function of Protein Bound Fatty Acyl Chains}

Understanding the function of protein linked acylchains in molecular terms requires some knowledge of the overall structure of the acylprotein and of the linkage site in particular. Since the small amounts of 
fatty acid (usually 1 - 2 chains per polypeptide; Schmidt, 1986) are not easily detected in low abundance proteins, radiolabeling with ${ }^{3} \mathrm{H}-$ myristic acid or ${ }^{3} \mathrm{H}$-palmitic acid and subsequent isolation of the protein with various established methods is applied. Figure 1 gives an example for the visualization of the acylated protein of influenza viruses, the small subunit $\mathrm{HA}_{2}$ of the viral hemagglutinin. Neither the large glycoprotein fragment of $\mathrm{HA}, \mathrm{HA}_{1}$, nor the membrane linked neuraminidase (NA) or the hydrophobic M-protein contain fatty acids.

(a)

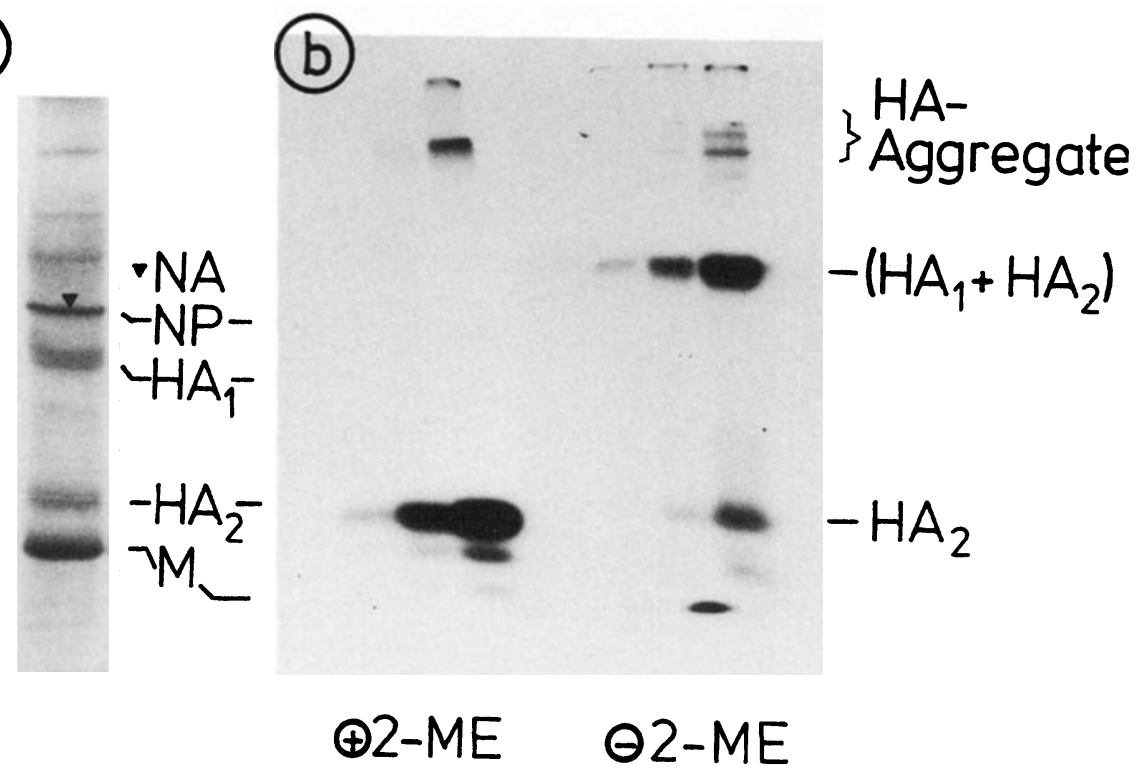

\section{Coomassie $\quad{ }^{3} \mathrm{H}$-Palmitic acid}

Figure 1: Acylproteins of Influenza Virus

PAGE-analysis of the proteins of ${ }^{3} \mathrm{H}-\mathrm{Pal}$ labeled influenza A virus (fowl plague virus) on $12 \%$ SDS-polyacrylamide gels with $6 \mathrm{M}$ urea. Panel a shows the Coomassie staining pattern and panel $b$ a fluorogram of viral proteins. In panel b $50 \mu \mathrm{g}, 300 \mu \mathrm{g}$ or $1 \mathrm{mg}$ viral protein were applied and the gel run under reducing (left side) or non-reducing conditions (right side). 
One step towards the topographical identification of acyl linkage sites in acylproteins has been the method of limited proteolysis. Since most of the virus particles with fatty acylated proteins are enveloped by a lipid bilayer, proteases can only digest the exposed peripheral portions of the relevant spike proteins. Thus, if ${ }^{3} \mathrm{H}-\mathrm{Pal}$ labeled virus is digested and subsequently centrifuged, supernatants with peripheral spike-peptides and sedimented "naked" virus particles can be analysed separately. Typical results obtained from such experiments are documented in table 6 and Fig. 2. After digesting ${ }^{3} \mathrm{H}-$ acylated and ${ }^{3} \mathrm{H}-\mathrm{glyco}-$ sylated virus particles, the distribution of radioactivity in supernatants and sediments is opposite for ${ }^{3} \mathrm{H}-\mathrm{glucosamine}$ labeled and ${ }^{3} \mathrm{H}-\mathrm{pal}-$ mitoylated peptides.

\section{TABLE 6}

\section{LIMITED DIGESTION OF 3 H-PAL LABELED INFLUENZA VIRUS}

\section{Radioactivity (cpm) in fractions}

$\begin{array}{lllcc}\text { Label } & \text { Treatment } & \text { Sediment } & \text { Supernatant } & \text { Total } \\ { }^{3} \mathrm{H}-\text { Palmitic acid } & \text { Control } & 263300 & 20600 & 283900 \\ & \text { Bromelain } & 268500 & 6600 & 275100 \\ -{ }^{3} \mathrm{H}-\text { Glucosamine } & \text { Control } & 55100 & 8000 & 63100 \\ & \text { Bromelain } & 15500 & 48200 & 63700\end{array}$

\footnotetext{
About $300 \mu \mathrm{g}$ of labeled fowl plague virus was digested for $3 \mathrm{~min}$ at $37^{\circ} \mathrm{C}$ in $100 \mu \mathrm{l}$ phosphate buffered saline (PBS) $\mathrm{pH} 7.4$ in the presence of $5 \mathrm{mM}$ dithiothreitol. After dilution with ice cold PBS the samples were centrifuged for $30 \mathrm{~min}$ at $45000 \mathrm{rpm}$ in a Beckman SW 50 Ti-rotor and radioactivity measured in aliquots of supernatants and pellets.
} 


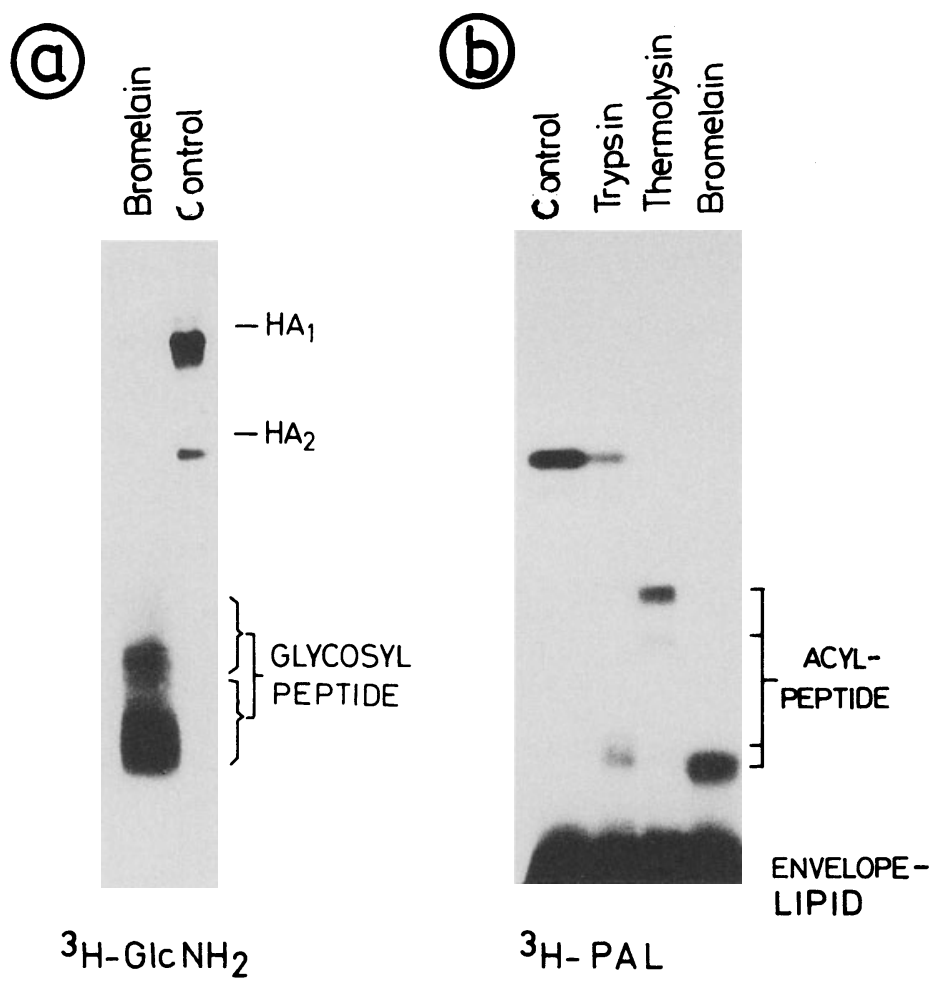

\section{Figure 2: Fatty Acylated Peptides of Influenza $\mathrm{HA}_{2}$}

${ }^{3} \mathrm{H}-$ Glucosamine $\left(\mathrm{GlCNH}_{2}\right)$ or ${ }^{3} \mathrm{H}$-palmitic acid (Pal) labeled influenza $\mathrm{A}$ virus (fowl plague) was subjected to limited proteolysis as described in the legend of table $6 .{ }^{3} \mathrm{H}-\mathrm{Gl} \mathrm{NNH}_{2}$ labeled peptides in the supernatant after bromelain digestion (panel a) and ${ }^{3} \mathrm{H}$-palmitoylated material in the sediments after trypsin, thermolysin and bromelain digestion were analysed on $15 \%$ SDS-gels. Fluorograms of the respective gels are shown.

In order to identify the nature of the radioactive material, the relevant fractions were subjected to PAGE-analysis on $15 \%$ SDS-polyacrylamide gels. The fluorograms of such gels shown in Fig. 2 reveal, that the ${ }^{3} \mathrm{H}-\mathrm{Pal}$ material in the sediments contains indeed defined ${ }^{3} \mathrm{H}-\mathrm{acy}-$ lated peptides beside the ${ }^{3} \mathrm{H}-1$ abeled bulk lipid of the viral envelope still present in "naked" particles. 


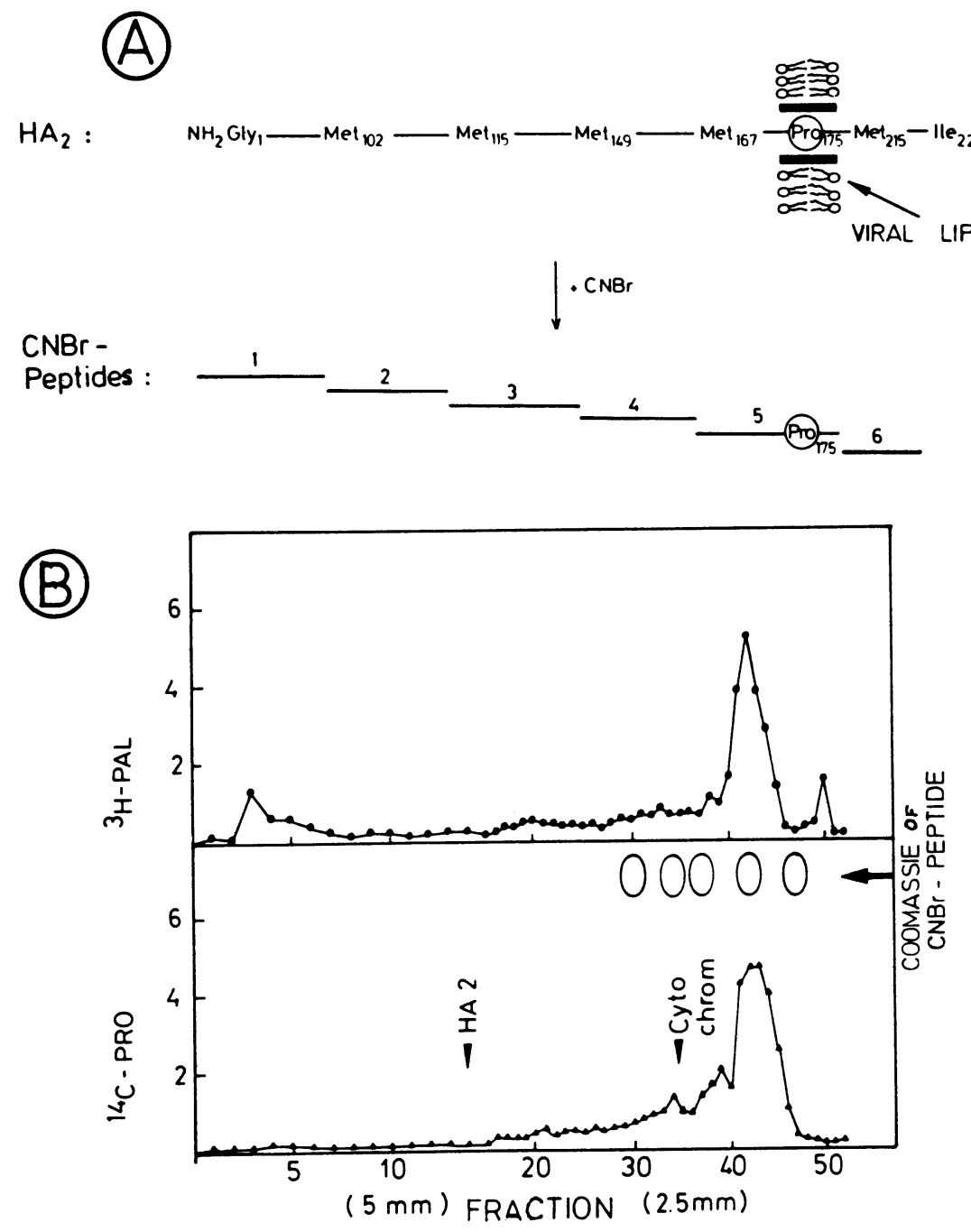

Figure 3: Cyanogen Bromide Cleavage of $\mathrm{HA}_{2}$

A, Schematic of the expected cleavage pattern of fowl plague virus HA at methionine residues.

B, PAGE-analysis of CNBr-peptides on $15 \%$ cylindrical SDS-polyacrylamide gels. The distribution of ${ }^{3} \mathrm{H}$-palmitic acid (PAL) and ${ }^{14} \mathrm{C}$-proline (PRO) in gel slices is shown. Prior to fractionation gels were stained with Coomassie and staining pattern is indicated by ovals in lower panel. The positions of non-treated $\mathrm{HA}_{2}$ and cytochrome $\mathrm{C}$ (Cyto) run as references are indicated by arrows. 
This can be taken as an indication that the linkage site is close to the region of $\mathrm{HA}_{2}$ which interacts with the viral lipid envelope.However more is required to prove this. One approach is to start with purified acylproteins, which seems most promising for proteins of which the aminoacid sequence is known. This is the case for the hemagglutinin (HA) of fowl plague virus (Porter et al., 1979) as well as for E1 and E2 of Semliki Forest virus (SFV; Garoff et al., 1980) which are discussed below.

As indicated in panel $\mathrm{A}$ of figure 3 fowl plague $\mathrm{HA}$ offers a promising fragment pattern if cyanogen bromide $(\mathrm{CNBr})$ is used as the cleavage reagent. If fatty acids are located in the membrane segment, then this same fragment should also contain the only proline residue present in this $\mathrm{HA}_{2}$. PAGE-analysis of CNBr-fragments generated in such an experiment show that ${ }^{3} \mathrm{H}-\mathrm{Pal}$ and ${ }^{14} \mathrm{C}-\mathrm{Pro}$ labeled peptides run to the same position, which substantiates the above hypothesis that the acylation site is located near to the membrane. Furthermore, the realistic possibility that more peripheral regions of $\mathrm{HA}_{2}$ are acylated which potentially could loop back into the viral bilayer (compare ${ }^{3} \mathrm{H}-\mathrm{Gl}_{\mathrm{CNH}}$ radioactivity in sediment in table 6) has been excluded by this latter finding (Figure 3, panel B).

All our attempts to cleave the acylated CNBR-peptide of $\mathrm{HA}_{2}$ further in order to isolate short peptides for sequence studies failed because of apparently adverse properties of such material. For this reason we chose a viral acylprotein, which can be purified to higher yields and the primary structure of which is known, the SFV-E1 (Garoff et al., 1980). E1-pro'ein from ${ }^{3} \mathrm{H}$-palmitoylated SFV digested with chymotryp- 
sin yielded only one ${ }^{3} \mathrm{H}$-acylated peptide of about 6000 dalton (Figure 4, lanes 1 and 2). Likewise, digestion of the more heavily acylated SFV-E2 with Staph. aureus protease V8 yielded several defined ${ }^{3} \mathrm{H}$-acylpeptides (Figure 4, lanes 3 and 4 ).

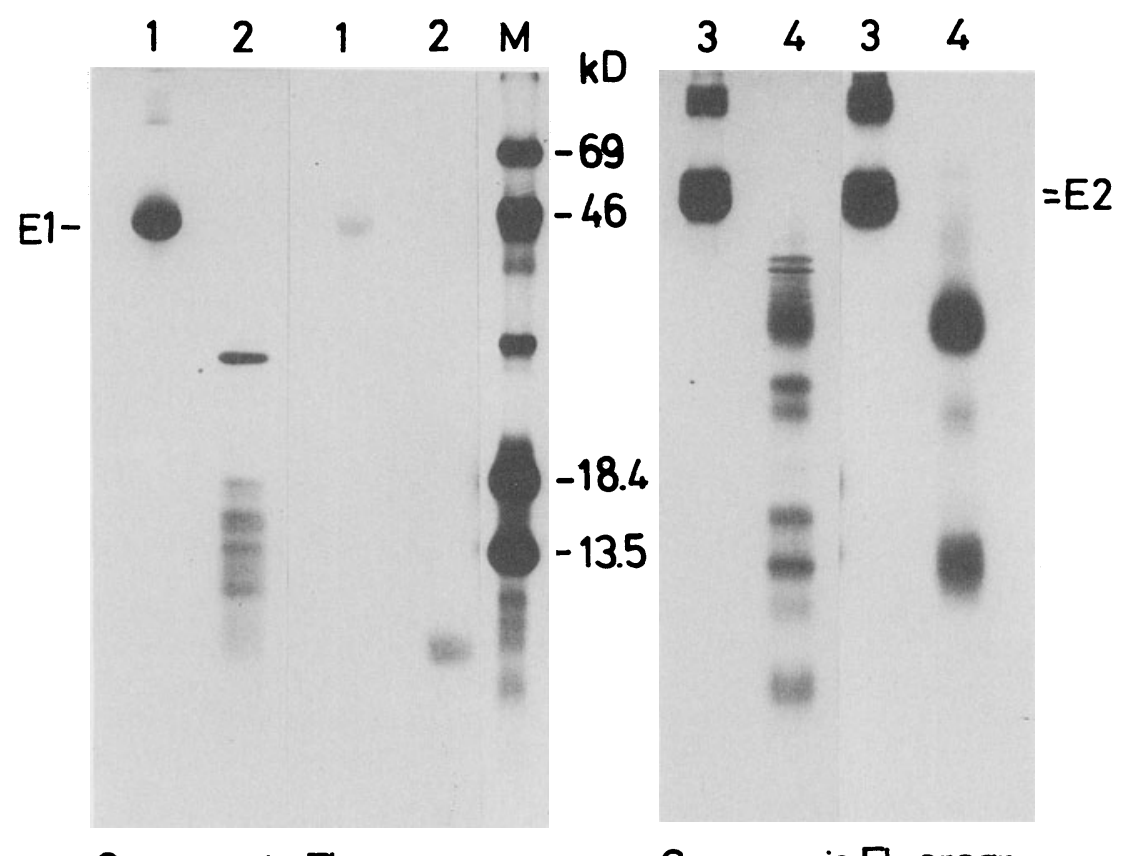

Coomassie Fluorogram Coomassie Fluorogr.

Figure 4: Proteolytic Digestion of ${ }^{3} \mathrm{H}-\mathrm{Acy} 1 \mathrm{E} 1$ and $-\mathrm{E} 2$ from Semliki Forest Virus

Acylproteins were isolated from purified ${ }^{3} \mathrm{H}$-palmitic acid labeled SFV and digested with chymotrypsin (E1-protein, lanes 2) or with V8-protease (E2-protein, lanes 4) and run on 15\% SDS-polyacrylamide gels. Coomassie staining patterns and fluorograms of the same gels are shown. Nontreated E1 and E2 are shown in lanes 1 and lanes 3, respectively.

Since it was found unsuitable to isolate acylpeptides from polyacrylamide gels (unacceptable losses), separation was attempted by utilizing reversed phase materials. The best results have been achieved with chymotryptic peptides of E1. The digest was loaded onto Sep-Pak cartridges in $60 \%$ formic acid and then eluted stepwise with increasing 
concentrations of $\mathrm{n}$-propanol. The distribution of ${ }^{3} \mathrm{H}-\mathrm{Pal}$ in the various fractions shown in table 7 reveals the expected high solubility of ${ }^{3} \mathrm{H}$-acylated peptide in fractions with high $\mathrm{n}$-propanol concentration.

\section{TABLE 7}

\section{ELUTION OF CHYMOTRYPTIC PEPTIDES FROM ${ }^{3}$ H-PALMITOYLATED SFV-E1}

$\begin{array}{ccccc}\text { Fraction } & \text { Eluent } & 3 \text { H-Pal (cpm) } & \text { Percent of Total } \\ 1 & & \text { SDS (0.1\%) } & 63875 & 30.3 \\ 2 & \text { O\% n-Propanol } & 9430 & 4.5 \\ 3 & 3 \% & \text { " } & 4980 & 2.4 \\ 4 & 8 \% & \text { " } & 3910 & 1.8 \\ 5 & 25 \% & 16890 & 8 \\ 6 & 40 \% & " & 55480 & 26.3 \\ 7 & 80 \% & \text { " } & 56200 & 26.7\end{array}$

Table 7: The digest in $0.1 \%$ SDS was loaded onto $C 18$ reversed phase SepPak cartridges. After washing several times with water step elution was started with $60 \%$ formic acid and increasing concentrations of n-propanol. Radioactivity was measured by scintillation counting of aliquots.

Amino acid analysis of fractions revealed that after elution with $25 \%$ n-propanol more than $80 \%$ of all peptides had been eluted. Fraction 6 (40\% n-propanol in $60 \%$ formic acid) was chosen for further purification by HPLC on a C4-wide pore column. As shown in figure 5 the ${ }^{3} \mathrm{H}$-acylpeptide elutes at a concentration of about $65 \%$ 2-propanol in $0.1 \%$ trifluoroacetic acid (TFA).

Our attempts to sequence the fraction containing radiolabeled peptides failed because of the extremely hydrophobic properties of this material. To identify the peptide we utilized amino acid analysis by the Pico-Tag method (Waters) by which the phenylthiocarbamyl (PTC) amino 


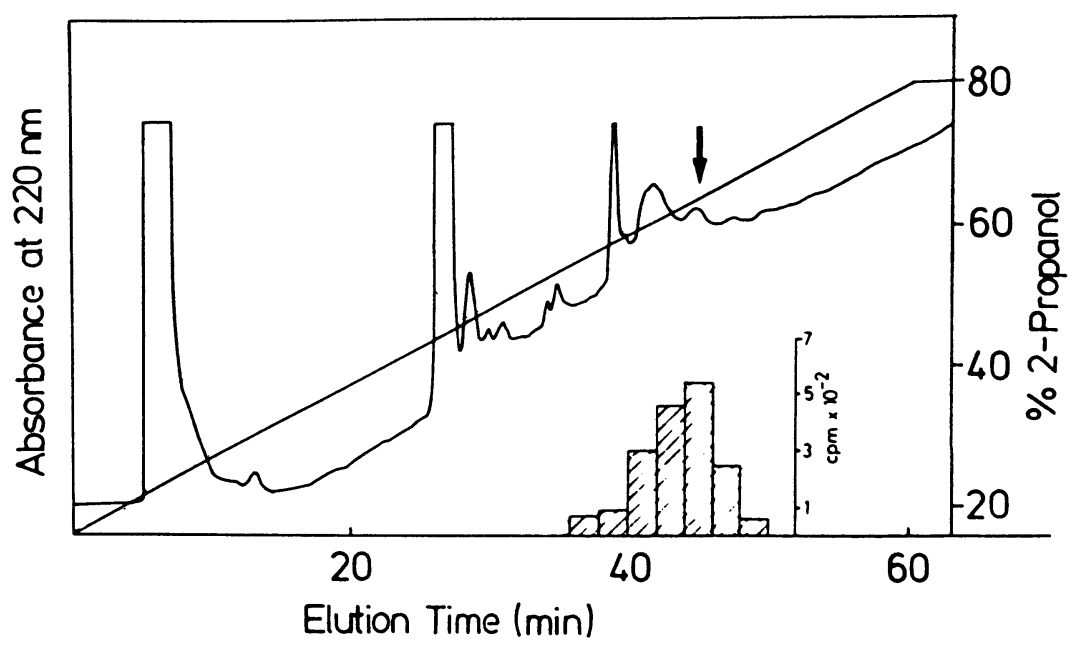

Figure 5: HPLC of Chymotryptic Peptides of ${ }^{3} \mathrm{H}-\mathrm{Pal}$ labeled SFV-E1

Prepurified ${ }^{3} \mathrm{H}-\mathrm{Acyl}$ peptides from E1 (fraction 6 from elution shown in table 7) were applied to a wide pore reversed phase column (Organogen, Heidelberg). Elution was with a gradient from 20-80\% 2-propanol in TFA at a flow rate of $0.6 \mathrm{ml} / \mathrm{min}$. Protein was monitored at $220 \mathrm{~nm}$ and radioactivity was measured by scintillation counting.

acids are separated. The results shown in table 8 strongly suggest that, as with the influenza $\mathrm{HA}$, also the ${ }^{3} \mathrm{H}$-acylated peptide isolated from SFV-E1 originates from the carboxyterminnus of E1 (compare figure 6).

Recently experiments are underway to sequence this material on solid phases. Preliminary results indicated alanin residues both in the first and second step (compare Fig. 5). Thus, we have purified fatty acylated peptide material which upon sequence analysis will eventually yield the precise linkage site of palmitic acid. This type of analysis, the protein chemical study of the "real thing" is tidious and hitherto only in one case has an acyl linkage site for palmitic acid been determined, a threonine residue in lipophilin from bovine brain (Stoffel, 1983). 
TABLE 8

AMINO ACID ANALYSIS OF 3 H-ACYLPEPTIDE FROM E1

Amino Acid

$\underline{\text { H-Acylpeptide }}$

Theoretical Peptide

(Pos. $400-438$ in Fig. 6)

$\begin{array}{lcc}\text { Asp } & 1 & 1 \\ \text { Glu } & 1-2 & 1 \\ \text { Ser } & 4 & 3 \\ \text { Gly } & (10 ?) & 6 \\ \text { His } & - & - \\ \text { Arg } & 1-2 & 2 \\ \text { Thr } & 2 & 2 \\ \text { Ala } & 4 & 4 \\ \text { Pro } & 1 & 1 \\ \text { Tyr } & - & - \\ \text { Val } & 2-3 & 5 \\ \text { Met } & 0-1 & 1 \\ \text { Cys } & - & 1 \\ \text { Ile } & & 4 \\ \text { Leu } & 4 & 5 \\ \text { Phe } & 1 & 1 \\ \text { Lys } & 1-2 & 1\end{array}$

Table 8: HPLC-fractions containing the ${ }^{3} \mathrm{H}-\mathrm{Pal}$ labeled peptides (arrow in Fig. 5) were hydrolysed for $24 \mathrm{~h}$ at $110^{\circ} \mathrm{C}$ in $6 \mathrm{~N} \mathrm{HCl}$. After derivation with phenylisothiocyanate according to the PICO-TAG procedure (Waters) the PTC-derivatives were separated by HPLC with a gradient from 6 to $46 \%$ acetonitril in $0.14 \mathrm{M}$ sodium acetate with $0.05 \%$ (v/v) triethylamin. PTC-amino acids were detected at $254 \mathrm{~nm}$.

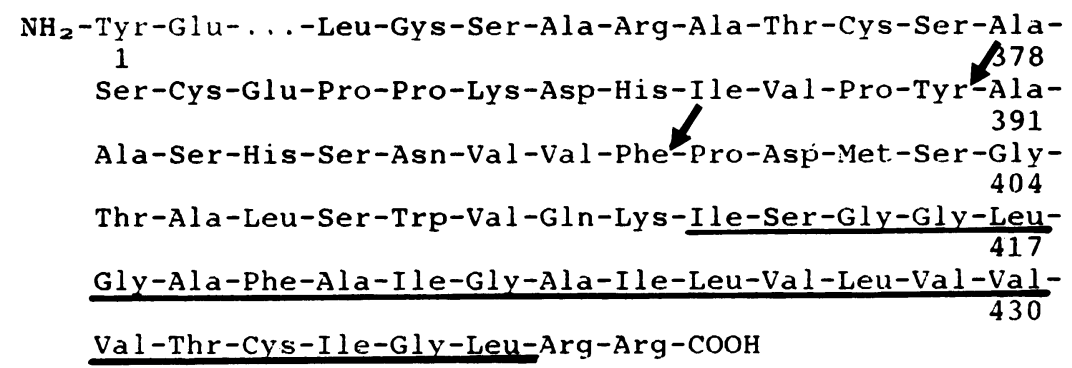

Figure 6: Genome derived amino acid sequence of the carboxyterminal region of SFV-1

Only the aminoterminus and the last 70 carboxyterminal amino acids given as determined by Garoff et al. (1980). The potential chymotrypsin cleavage sites are indicated by arrows. The membrane spanning segment is underlined. 
However, identification and sequencing of acylpeptides seems advantageous over the gene technological approach. With this latter technique acylation is studied by expresion of genes in which potential acylation sites (Cys, Ser, Thr) have been replaced. In a number of cases Cys has been suggested to be the linkage site, because its replacement by ser or other amino acids led to a loss of acylation (Willumsen et al., 1984; Koch and Hämmerling, 1986; Rose et al., 1984; Jing and Trowbridge, 1987). Such interpretations are certainly valid but not compelling. Replacement of cystein residues may lead to an alteration of the structure of a protein such that other acylation sites may not be available for the biosynthetic acylation which seems to be a membrane located process involving specific enzymes (Berger and Schmidt, 1984; Schmidt, 1984; Mack et al., 1987). For this reason further results of palmitic acid linkage analyses on the protein level will have to be awaited before any general conclusions can be drawn on consensus sequences for palmitoylation. It should be noted that for myristilation much more structural information has become available due to the stability of the amide linkage between myristic acid and the aminoterminal glycine residue (see Sefton and Buss, 1987). On the basis of this information Glaser and coworkers recently succeeded in isolating a protein N-myristoyl-transferase from yeast (Towler et al., 1987).

Concerning the function of fatty acids in a protein more speculations are available in the literature than hard experimental results, particularly with palmitoylated proteins. The most intrinsing hypothesis for a general function of palmitoylation of cellular proteins was recently put forward by Glick and Rothman (1987). These 
authors reported that in an in vitro system protein transport through the Golgi-stack was stimulated by palmitoyl-CoA, wich is the known precursor for palmitoylation of proteins (Schmidt, 1984).

With viral structural acylproteins it was noted that many of these were fusogenic as their most prominent biological feature (Schmidt, 1982). In order to test the hypothesis that acyl chains are in some way involved in fusion induction, virus particles with acylated protein or detergent solubilized acylproteins were compared with their hydroxylamin deacylated counterparts in their fusogenic properties as measured by hemolysis and resonance energy transfer with N-NBD-PE and N-Rho-PE labeled liposomes (Struck et al., 1981). The results of such experiments utilizing influenza virus show clearly, that no fusion occurs between virus particles and cell membranes if the viral hemagglutinin $\mathrm{HA}_{2}$ is devoid of fatty acids. Similar results have been obtained with Semliki Forest- and Newcastle disease virus (Schmidt and Lambrecht, 1985; Lambrecht and Schmidt, 1986). It is therefore likely that with enveloped viruses protein bound fatty acids may be essential to initiate an infection by triggering the fusion between viral and cellular membranes.

In the myristilated transforming proteins (table 4) fatty acids are essential for anchoring the protein to the cytoplasmic face of the plasma membrane. If no myristic acid is present at their aminoterminus these proteins are found in the cytoplasm. As a consequence, the cells cannot be transformed and retain their normal phenotype (Kamps et al., 1986; Pellman et al., 1985). 


\section{Conclusion}

Although many acylproteins have been identified and many more with as yet unknown identities have been reported, quite little is known on the structure and function of protein bound acyl chains. Thus $f$ ar, in large the viral acylproteins can be regarded as the "avantgarde class of molecules" in the study of the various aspects of fatty acylation. Hopefully, as perhaps indicated by the recent identification of a protein myristoyl transferase (Towler et al., 1987) more data will become available in the near future on the linkage, enzymology and functional role of acyl chains in the ever increasing number of cellular acylproteins.

\section{Acknowledgement}

We thank Rudi Rott for continuous support and encouragement in our studies on acylation. All effort by Eva Kroell and Margot Seitz with editorial work and typing of the manuscript are gratefully acknowledged. Work herein has been supported by Sonderforschungsbereich 47 of the Deutsche Forschungsgemeinschaft and research initiation grant $M B$ 173 of Kuwait University. This work is presented in partial fulfillment of the requirements for Dr. rer. nat. of Marion Schmidt at the FB 15 of Justus-Liebig-Universität Giessen, FRG. 


\section{References}

Agrawal HC, Randle CL, Agrawal D (1982) In vivo acylation of rat brain myelin proteolipid protein. J Biol Chem 257:4588-4592

Agrawal HC, Schmidt RE, Agrawal D (1983) In vivo incorporation of $\left({ }^{3} \mathrm{H}\right)$ palmitic acid into PO protein, the major intrinsic protein of rat sciatic nerve myelin. J Biol Chem 258:6556-6560

Aitken A, Cohen P, Santikarn S, Williams DN, Calder AB, Smith A, Klee $C B$ (1982) Identificationof the $\mathrm{NH}_{2}$-terminal blocking group of calcineurin B as myristic acid. FEBS-Lett 150:7-12

Aitken A, Cohen P (1984) Identification of N-terminal myristyl blocking groups in proteins. Methods Enzymol 106:205-210

Bazan NG, Reddy TS, Redmond TM, Wiggert B, Chader GJ (1985) Endogeneous fatty acids are covalently and noncovalently bound to interphotoreceptor retinoid-binding protein in the monkey retina. $\mathrm{J}$ Biol Chem 260:13677-13680

Berger M, Schmidt MFG (1984) Cell free fatty acid acylation of Semliki Forest viral polypeptides with microsomal membranes from eukaryotic cells. J Biol Chem 259:7245-7252

Berger M, Schmidt MFG, (1986) Characterization of a protein fatty acylesterase present in microsomal membranes of diverse origin. J Biol Chem 261:14912-14918

Betz R, Crabb JW, Meyer HE, Wittig R, Duntze W (1986) Amino acid sequences of a factor mating peptides from Saccharomyces cerevisiae. J Biol Chem 262:546-548

Bolanowski MA, Earles BJ, Lennarz WJ (1984) Fatty acylation of proteins during development of sea urchin embryos. J Biol Chem 259: 4934-4940

Bordier C, Etges RJ, Ward J, Turner MJ, Cardoso de Almeida ML (1986) Leishmania and trypanosoma surface glycoproteins have a common glycophospholipid membrane anchor. Proc Natl Acad Sci 83:5988-5991

Bringman TS, Lindquist PB, Derynck $R$ (1987) Different transforming growth factor-a species are derived from a glycosylated and palmitoylated precursor. Cell 48:429-440

Burn P, Burger MM (1987) The cytoskeletal protein vinculin contains transformation sensitive, covalently bound lipid. Science 235:476479

Buss, JE, Sefton BM (1985) Myristic acid, a rare fatty acid, is the lipid attached to the transforming protein of Rous sarcoma virus and its cellular homolog. J Virol 53:7-12

Carr SA, Biemann K, Shoji S, Parmelee DS, Titani K (1982) n-Tetradecanoyl is the $\mathrm{NH}_{2}$-terminal blocking group of the catalytic subunit of the cyclic AMP-dependent protein kinase from bovine cardiac muscle. Proc Natl Acad Sci USA 79:6128-6131

Chow M, Newman JFE, Filman D, Hogle JM, Rawlands DJ, Brown F (1987) Myristilation of picornavirus capsid protein VP4 and its structural significance. Nature 327:482-486

Dolci ED, Palade GE (1985 The biosynthesis and fatty acid acylation of the murine erythrocyte sialoglycoproteins. J Biol Chem 260:1072810735

Ferguson MAJ, Haldar K, Cross GAM (1985) Trypanosoma brucei Variant Surface Glycoprotein has a sn-1,2-dimyristyl glycerol membrane anchor at its $\mathrm{COOH}$ terminus. J Biol Chem 260:4963-4968 
Firestone GL, Payvar F, Yamamoto KR (1982) Glucocorticoid regulation of protein processing and compartmentatization. Nature 300:221-225

Folch-Pi J, Lees M (1951) Proteolipids, a new type of tissue lipoproteins. Their isolation from brain. J Biol Chem 191:807-817

Fujiyama A, Tamanoi F (1986) Processing and fatty acylation of RAS1 and RAS2 proteins in Saccharomyces cerevisiae. Proc Natl Acad Sci USA 83:1266-1270

Garoff H, Frischauf AM, Simons K, Lehrach H, Delius H (1980) Nucleotide sequence of CDNA coding for Semliki Forest virus membrane glycoproteins. Nature 288:236-241

Gebhardt A, Bosch JV, Ziemiecki A, Friis RR (1984) Rous sarcoma virus p19 and gp35 can be chemically cross-linked to high molecular weight complexes - an insight into virus assembly. J Mol Biol 174:297-317

Grand RJA, Roberts C, Gallimore PH (1985) Acylation of Adenovirus type 12 early region $1 \mathrm{~b}$ 18-kDa protein. FEBS-Lett 181:229-235

Haldar K, Ferguson MAJ, Cross GAM (1985) Acylation of Plasmodium falciparum merozite surface antigen via sn-1,2-diacyl glycerol. $\mathrm{J}$ Biol Chem 260:4969-4974

He H-T, Barbet J, Chaix J-C, Goridis C (1986) Phosphatidylinositol is involved in the membrane attachment of NCAM-120, the smallest component of the natural cell adhesion molecule. EMBO-J 2:2489-2494

Hiller G, Weber K (1985) Golgi-derived membranes that contain an acylated viral polypeptide are used for vaccinia virus envelopment. $\mathrm{J}$ Virol 55:651-659

Hoeg JM, Meng MS, Ronan R, Fairwell T, Brewer jr HB (1986) Human apoliprotein A-I. Post-translational modification by fatty acid acylation. J Biol Chem 261:3911-3914

Jing S, Trowbridge IS (1987) Identification of the intermolecular disulfide bonds of the human transferrin receptor and its lipidattachment site. EMBO-J 6:327-331

Johnson DC, Spear PG (1983) O-linked oligosaccharides are acquired by Herpes simplex virus glycoproteins in the Golgi apparatus. Cell 32: $987-997$

Kamps MP, Buss JE, Sefton BM (1986) Rous sarcoma virus transforming proteins lacking myristic acid phosphorylates known polypeptide substrates without inducing formation. Cell 45:105-112

Kaufmann JF, Krangel MS, Strominger JL (1984) Cysteines in the transmembrane region of major histocompatibility complex antigens are fatty acylated via thioester bonds. J Biol Chem 259:1-9

Keenan TW, Heid HW, Stadler J, Jarasch ED, Frankke WW (1982) Tight attachment of fatty acids to proteins associated with milk lipid globule membrane. Eur J Cell Biol 26:270-276

Kellie AE, Wrigglesworth $P$ (1987) Vinculin is myristilated. FEBS-Lett $213: 428-432$

Kinet JP, Quarto R, Perez-Monfort R, Metzger H (1985) Noncovalently and covalently bound lipid on the receptor for immunoglobulin $E$. Biochemistry 24:7342-7348

Klockmann U, Deppert W (1983) Acylated Simian virus 40 large T-antigen: a new subclass associated with a detergent-resistant lamina of the plasma membrane. EMBO J 2:1151-1157

Koch N, Hämmerling GJ (1985) The Ia associated invariant chain is fatty acylated before addition of sialic acid. Biochemistry 24:61856190 
Koch N, Hämmerling GJ (1986) The HLA-D-associated invariant chain binds palmitic acid at the cysteine adjacent to the membrane segment. J Biol Chem 261:3434-3440

Lambrecht B, Schmidt MFG (1986) Membrane fusion induced by influenza virus hemagglutinin requires protein bound fatty acids. FEBS-Lett $202: 127-132$

Lange-Mutschler $J$ (1986) Acylated fibronectin: a new type of posttranslational modification of cellular fibronectin. FEBS-Lett $201: 210-214$

Low MG, Zilversmit DB (1980) Role of phosphatidylinositol in attachment of alkaline phosphatase to membranes. Biochemistry 19:3913-3918

Low MG, Ferguson MAJ, Futerman AH, Silman I (1986) Covalently attached phosphatidylinositolas a hydrophobic anchor for membrane proteins. Trends Biochem Sci 244.1-13

Mac Lennan DH, Yip CC, Iles GH, Seeman P (1972) Isolation of sarcoplasmic reticulum protein. Cold spring Harbour symp Quant Biol $27: 469-477$

Madoff DH, Lenard J (1982) A membrane glycoprotein that accumulates intracellularly: cellular processing of the large glycoprotein of La Crosse virus. Cell 28:821-829

Mack D, Berger M, Kruppa J, Schmidt MFG (1987) In vitro-acylation of the VSV G-protein with microsomal membranes from cultured cells. J Biol Chem 262:4297-4302

Magee AI, Courtneidge SA (1985) Two classes of fatty acid acylated proteins exist in eukaryotic cells. EMBO-J 4:1137-1144

Magee AI, Siddle K (1986) Human insulin rezeptor contains covalently bound palmitic acid. Biochem Soc Trans 14:1103-1104

McIlhinney RAJ, Pelly SJ, Chadwick JK, Cowley GP (1985) studies on the attachment of myristic and palmitic acid to cell proteins in human squamous carcinoma cell lines: evidence for two pathways. EMBO-J $4: 1145-1152$

Medof ME, Walter EI, Roberts WL, Haas R, Rosenberry TL (1986) Decay accelerating factor of complement is anchored to cells by a C-terminal glycolipid. Biochemistry 25:6740-6747

Merz DC, Wolinski JS (1983) Conversion of nonfusing mumps virus infections by selective proteolysis of the HN glycoprotein. Virology $131: 328-340$

Moremen KW, Touster $O$ (1985) Biosynthesis and modification of Golgi mannosidase II in HeLa and 3T3 cells. J Biol Chem 260:6654-6662

Nakabayashi T, Ikezawa H (1984) PI-Anchors of alkaline phosphodiesterase and 5'nucleotidase. Cell struct Funct 9:247

O'Brien PJ, Zatz M (1984) Acylation of bovine rhodopsin by ${ }^{3} \mathrm{H}$-palmitic acid. J Biol Chem 259:5054-5057

Olson EN, Glaser L, Merlie JP (1984) Alpha- and beta-subunits of the nicotinic acetylcholine receptor contain covalently bound lipid. J Biol Chem 259:5364-5367

Omary MB, Trowbridge JS (1981) Biosynthesis of the human transferrin receptor in cultured cells. J Biol Chem 256:12888-12892

Ozols J, Carr SA, strittmatter $P$ (1984) Identification of the $\mathrm{NH}_{2}$-terminal blocking group of $\mathrm{NADH}$-cytochrome $\mathrm{b}_{5}$ reductase as myristic acid and the complete amino acid sequence of the membrane binding domain. J Biol Chem 259:13349-13354 
Pellman D, Garber EA, Cross FR, Hanafusa H (1985) An N-terminal peptide from p60src can direct myristilation and plasma membrane localization when fused to heterologous proteins. Nature 314:344-347

Porter AG, Barber C, Carey NH, Hallewell RA, Threlfall G, Emtage JS (1979) Complete nucleotide sequence of an influenza virus hemagglutinin gene from cloned DNA. Nature 282:471-477

Roberts WL, Rosenberry TL (1985) Identification of covalently attached fatty acids in the hydrophobic membrane-binding domain of human erythrocyte acetylcholin esterase. Biochem Biophys Res Com 133:621627

Rose JK, Adams GA, Gallione CJ (1984) The presence of cysteine in the cytoplasmic domain of the Vesicular stomatitis virus glycoprotein is required for palmitate addition. Proc Natl Acad Sci USA 81:2050-2054

Schmidt MFG, Bracha M, Schlesinger MJ (1979) Evidence for covalent attachment of fatty acids to Sindbis virus glycoproteins. Proc Natl Acad Sci USA 76:1687-1691

Schmidt MFG, Schlesinger MJ (1979) Fatty acid binding to Vesicular Stomatitis virus glycoprotein - a new type of posttranslational modification of the viral glycoprotein. Cell 17:813-819

Schmidt MFG (1982) Acylation of viral spike glycoproteins - a feature of enveloped RNA-viruses. Virology 116:327-338

Schmidt MFG (1983) Fatty acid binding: a new kind of posttranslational modification of membrane proteins. Curr Top Microbiol Immunol $102: 101-129$

Schmidt MFG (1984) The transfer of myristic- and other fatty acids on lipid- and viral protein acceptors in cultured cells infected with Semliki Forest- and Influenza virus. EMBO-J 3:2295-2300

Schmidt MFG (1986) Die Acylierung von Proteinen mit Fettsäuren, Habilitationsschrift, Justus-Liebig-Universität Giessen, FRG

Schmidt MFG, Lambrecht B (1985) on the structure of the acyl linkage and the function of fatty acyl chains in the influenza virus hemagglutinin and the glycoproteins of Semliki Forest virus. J gen Virol $66: 2635-2647$

Schultz AM, Oroszlan S (1983) In vivo modification of retroviral gag gene-encoded polyproteins by myristic acid. J Virol 46:355-361

Schultz AM, Oroszlan S (1984) Myristilation of gag-onc fusion proteins in mammalian transforming retroviruses. Virology 133:431-437

Schultz AM, Copeland TD, Mark GE, Rapp UR, Oroszlan S (1985) Detection of the myristylated gag-raf transforming proptein with raf-specific antipeptide sera. Virology $146: 78-83$

Schultz AM, Henderson LE, Oroszlan S, Garber EA, Hanafusa H (1985) Aminoterminal myristilation of protein kinase p60src, a retroviral transforming protein. Science 227:427-429

Sefton BB, Trowbridge IS, Cooper JA, Scolnick EM (1982) The transforming proteins of Rous sarcoma virus and Abelson virus contain tightly bound lipid. Cell 31:465-474

Sefton BM, Buss JE (1987) The covalent modification of eukaryotic proteins with lipid. J Cell Biol 104:1449-1453

Slomiany A, Witas H, Aono M, Slomiany BL (1983) Covalently linked fatty acids in gastric mucus glycoproteins of cystic fibrosis patients. J Biol Chem 258:8535-8538 
Soric J, Gordon JA (1985) The 36-kilodalton substrate of pp60v-src is myristilated in a transformation-sensitive manner. Science 230:563566

Staufenbiel M, Lazarides E (1986) Ankyrin is fatty acid acylated in red blood cells. Jahrestagung d. Dt. Gesellsch. f. Zellbiol. Tübingen.

Stoffel W., Hillen H., Schröder W, Deutzmann W (1983) The primary structure of bovine brain myelin lipophilin (proteolipid apoprotein). Hoppe-Seyler's Z Physiol Chem 364:1455-1466

Streuli $\mathrm{CH}$, Griffin BE (1987 Myristic acid is coupled to a structural protein of polyoma virus and SV40. Nature 326:619-622

Strous GJ, van Kerkhof P, WillemsenR, Berger EG (1983) Role of oligosaccharides in the metabolism of the Golgi enzyme galactosyltransferase. In: Proceedings of the 7 th International symposium on Glycoconjugates (Chester MA, Heinegard D, Lundblad A, Svenson S, Lund S, eds) pp 753-754

Struck DK, Hoekstra D, Pagano RE (1981) Use of resonance energy transfer to monitor membrane fusion. Biochemistry 20:4093-4099

Takesue Y, Yokota K, Nishi Y, Taguchi R, Ikezawa H (1986) Solubilization of trehalase from rabbit renal and intestinal brush-border membranes by a phosphatidylinositol-specific phospholipase G. FEBSLett 201:5-8

Towler DA, Adams SP, Eubanks SR, Towery DS, Jackson-Macheliski E, Glaser L, Gordon JI (1987) Purification and characterisation of yeast myristoyl COA: protein N-myristoyltransferase. Proc Natl Acad Sci $84: 2708-2712$

Tse AGD, Barclay AN, Watts A, Williams AF (1985) A glycophospholipid tail at the carboxyl terminus of the Thy-1 glycoprotein of neurons and thymocytes. Science 230:1003-1008

Voronova AF, Buss JE, Patschinsky T, Hunter T, Sefton BM (1984) Characterization of the protein apparently responsible for the elevated tyrosine protein kinase activity in LSTRA cells. Mol Cell Biol $4: 2705-2713$

Willumsen BW, Norris K, Papageorge AG, Hubbert NL, Lowy D (1984) Harvey murine sarcoma virus p21 ras protein: biological and biochemical significance of cysteine nearest carboxyterminus. EMBO-J 3:2581-2585

Yang JC, Chang PC, Fujitaki JM, Chiu KC, Smith RA (1986) Covalent linkage of phospholipid to myelin basic protein: Identification of phosphatidylinositol bisphosphate as the attached phospholipid. Biochemistry 25:2677-2681 